\title{
確率的潜在意味解析とシミュレーションによる決定方略の推定
}

\author{
$\bigcirc$ 玉利祐樹 ${ }^{1} \cdot$ 井出野尚 $^{2} \cdot$ 竹村和久 ${ }^{3}$ \\ ( 1 静岡県立大学経営情報学部・ ${ }^{2}$ 徳山大学経済学部 $\cdot{ }^{3}$ 早稲田大学文学学術院 $)$ \\ キーワード : 決定方略, 言語プロトコル, トピックモデル
}

\section{Estimating decision strategies by probabilistic latent semantic indexing and simulation Yuki TAMARI ${ }^{1}$, Takashi IDENO ${ }^{2}$ and Kazuhisa TAKEMURA ${ }^{3}$}

( ${ }^{1}$ School of Management and Information, Univ. of Shizuoka, ${ }^{2}$ Faculty of Economics, Tokuyama Univ.,

${ }^{3}$ Fuculty of Letters, Arts and Sciences, Waseda Univ.)

Key Words: Decision strategy, verbal protocol, topic model

\section{目 的}

多肢多属性意思決定状況において, 選択肢・属性の数, 呈 示方法といった様々な要因に依存して, 走查される属性の順 序や選択結果が異なることが知られている。このような意思 決定の状況依存的な側面を記述するために, 様々な決定の仕 方（決定方略）が見いだされてきた（Payne，Bettman， and Johnson，1993）。その一方で，決定方略の分析および，その 適用においては，定性的な記述に留まっていると言える。そ こで, 本研究では, 言語プロトコルデータを対象に, 確率的 潜在意味解析および, 計算機シミュレーションを用いて, 決 定方略の観点から言語プロトコルデータの定量的分析の検討 を行った。

\section{方 法}

調査 原子力発電所がある町, 出身地の町についての絵と, それぞれの描画について思いつく形容詞の回答を求め, また 九つのリスク事象（アルコール飲料, 遺伝子組み換え食品, 原子力発電, 航空機事故, 自動車事故, 水力発電, 台風, 地 球温暖化，自身）を対象に, Slovic（1987）を改変したリス ク尺度への回答を求めた。以降の分析では, 形容詞データの みを分析に用いた。

調査参加者 大学生 98 名（平均年齢 20.31 歳, SD1.30, 女 性 56 名, 男性 42 名）に，集団にて実施した。上記調查への 回答に欠損のあった参加者を除き，92 名を分析対象とした。

計算機シミュレーション 形容詞データを用いて, 多属性 意思決定過程における決定方略の計算機シミュレーションを 行った。決定方略は, 加算型, 加算差型, 連結型, 分離型, EBA 型, 辞書編纂型を用いた。本シミュレーションで用いら れる属性一の重要度の推定および, 利得行列の設定は, 以下 の通りであった。

重要度の推定 形容詞データに形態素解析を行い, 名詞, 形容詞, 動詞を抽出した。2 回以上出現する品詞を対象に, 情報検索の分野で開発された確率的潜在意味解析 (Hofmann, 1999）を行った。抽出するトピック数は, 品詞と回答者の共 起行列の固有值次元の $20 \%$ に相当する 18 個とした。トピック の出現確率と, 各トピックにおいて品詞が出現する確率を推 定した。また, 両確率の積和を求め, 品詞一の重要度とした。

利得行列の設定 居住寸る町の選択と仮定し, 原子力発電 所がある町, 出身地の町を選択肢とした。品詞を属性として 扱い，ポジティブ，中立，ネガティブで評価できると考えら れる品詞に, それぞれ $3,2,1$ と得点を割り振った。出現し ていない品詞は 0 とした。

推定 シミュレーションの試行回数は, 方略每に 10,000 回 とした。走查される属性の順序が結果に与える影響を考慮し て, 1 試行每に, 重要度, 利得行列の順序をランダムに並び 替えた。また, 1 試行毎に, 走查された属性, 選択肢, およ びその順序を記録した。最も頻度が高かった属性, 選択肢を， ある順序における属性，選択肢とした。

\section{結 果}

決定方略毎に, 品詞の出現頻度を集計し, 形容詞デー夕に おける品詞の出現頻度との間の相関係数を求めた (Table 1)。 辞書編纂型, 加算型, 加算差型との間に有意な相関係数が認 められた。また, 辞書編纂型との相関係数が最も高い相関係 数であった $(r=.81)$

Table 1

形容詞データと決定方略における品詞の出現頻度の相関係数

\begin{tabular}{llll}
\hline & 加算型 & 加算差型 & 連結型 \\
\hline 形容詞 & $.21 *$ & .21 & $*$ \\
\hline & & -10 \\
\hline & 分離型 & $\mathrm{EBA}$ 型 & 辞書編纂型 \\
\hline 形容詞 & .03 & .07 & $.81 \quad * * *$ \\
\hline$* p<.05, * * * p<.001$ & &
\end{tabular}

\section{考 察}

計算機シミュレーションおよび相関分析の結果から, 本調 查における回答は, 辞書編纂型に最も類似した情報処理が行 われていた可能性が示唆された。本調査では, 二つの町につ いての回答を求める形式であり, 二つの町についての差異を 明確にする情報に注目が向きやすい課題であったため, 辞書 編纂型と最も類似する結果を示したと考えられる。

以上の分析から, 確率的潜在意味解析と計算機シミュレー ションを用いた分析枠組みから, 言語プロトコルデータが持 つ情報処理に関する情報を, 定量的に検討できる可能性が示 唆された。今後は, 推定された決定方略による選択の説明可 能性を検討する必要があると考えられる。また, 従来行われ てきている実験場面における情報モニタリング法, 眼球運動 測定データから推定された決定方略や選択との関係を検討す る必要がある。

\section{引用文献}

Hofmann, T. (1999, July). Probabilistic latent semantic analysis. In Proceedings of the Fifteenth Conference on Uncertainty in Artificial Intelligence (pp. 289-296). Morgan Kaufmann Publishers Inc..

Payne, J. W., Bettman, J. R., \& Johnson, E. J. (1993). The adaptive decision maker. Cambridge University Press.

Slovic, P. (1987). Perception of risk. Science, 236(4799), 280-285. 竹村和久 - 原口僚平 - 玉利祐樹 (2015). 多属性意思決定過程 における決定方略の認知的努力と正確さ : 計算機シミュレ ーションによる行動意思決定論的検討 認知科学, 22 , 368-388.

本研究は，科研費若手（B）16K17290の助成を受けたもの である。 